\title{
Naval Blockade and the Humanitarian Crisis in Yemen
}

\author{
Martin D. Fink ${ }^{1}$
}

Published online: 8 August 2017

(C) The Author(s) 2017. This article is an open access publication

\begin{abstract}
A Saudi Arabia-led coalition is supporting the Yemeni Government with military means against the Houthis in Yemen. Part of those military operations are naval operations off the coast of Yemen that aim to stop the influx of weapons meant for the Houthis. It is viewed that these naval enforcement measures, often termed blockade, have a severe impact on the dire humanitarian situation in Yemen. As the blockade is seen to cause severe humanitarian distress and is leading to starvation, many feel that it has been unlawfully established. The law of blockade is a specific legal regime that regulates how belligerent blockades can be lawfully established and enforced. The question, however, is whether a belligerent blockade has in fact been established in the case of Yemen and whether, considering the circumstances of the Yemeni conflict, the law of blockade applies.
\end{abstract}

Keywords Naval blockade - Yemen - Starvation · Houthis · Law of naval warfare - Naval enforcement measures · Humanitarian distress · Arms embargo

\section{Introduction}

In March 2015, a Saudi Arabia-led coalition supporting the Yemeni Government to bring a halt to the advancement of the Houthis in Yemen also commenced naval operations off the coast of Yemen as part of their military

Martin D. Fink

Finkmd@hotmail.com

1 Amsterdam Centre for International Law (ACIL), University of Amsterdam, Amsterdam, The Netherlands 
operations. ${ }^{1}$ A part of these naval operations consists of naval enforcement measures to stop the influx of weapons meant for the Houthis. In public reporting on the conflict these measures have consistently been called a 'naval blockade'. Throughout the conflict it has been opined that this blockade is causing severe humanitarian distress to the civilian population in an already battle-devastated Yemen. What follows from this dire humanitarian situation is that according to many observers these measures are unlawful. Interestingly, the coalition naval operations in relation to the Yemeni conflict bring together a number of issues with regard to the international law of military operations that still remain uncharted waters. Three of those issues are the establishment of naval blockades in non-international armed conflicts (NIACs), humanitarian considerations in relation to naval blockades, and whether the international law of the sea allows for measures to be taken during a NIAC conflict that de facto would establish measures similar to a belligerent blockade. Some of these issues gained some scholarly attention during the well-known Gaza flotilla incident in May 2010. This has, however, not resulted in a more thorough legal debate concerning these matters. The 'Yemen blockade' is yet another case from current practice that raises these questions. A discussion on the legality of the naval operations off the coast of Yemen might, therefore, help bring about a broader legal discussion on the application of the law of blockade in modern conflicts.

This article will discuss the legal bases for the naval enforcement measures imposed by the Saudi-led coalition against the Houthi opposition. I will begin with a short history of the Yemeni situation, which is necessary in order to be able to further proceed with some legal remarks on the situation. The legal analysis is subdivided into four questions: does the law of naval warfare (the law of blockade in particular) apply in the Yemeni situation; has a blockade been established stricto sensu; are there other possible legal bases for the coalition's naval enforcement measures; and finally, how does the humanitarian situation reflect on the legality of the naval enforcement measures?

\section{Operations Decisive Storm and Renewal of Hope}

The Saudi Arabia-led coalition operation Decisive Storm commenced at the end of March 2015. The military operations include a naval dimension. The military involvement of the coalition in this conflict between the Yemeni Government and the Houthis began at the request of the ousted Yemeni Government. The support of the coalition to the Yemeni Government was underlined in a letter to the UN Security Council (UNSC), which included Yemen's request in the following text:

I therefore appeal to you, and to the allied States that you represent, to stand by the Yemeni people as you have always done and come to the country's aid. I urge you, in accordance with the right of self-defence set forth in Article 51 of the Charter of the United Nations, and with the Charter of the League of Arab States and the Treaty on Joint Defence, to provide immediate support in

\footnotetext{
1 The coalition includes Bahrain, Egypt, Jordan, Kuwait, Morocco, Qatar, Sudan and the United Arab Emirates.
} 
every form and take the necessary measures, including military intervention, to protect Yemen and its people from the ongoing Houthi aggression,...

From the outset, coalition naval forces were involved in attacking targets situated on land and employed to stop arms meant for the opposing party flowing into Yemen. For the latter purpose, by the end of March the coalition stated it was going to impose a blockade of Yemeni ports to stop the influx of arms getting into the hands of the Houthis. ${ }^{3}$ On 10 April 2015, the Yemeni Government issued a statement in which it stated it would close its territorial waters to commercial and humanitarian shipping. Entry into the territorial waters would now only be granted with permission from the Yemeni Government. The statement mentions that:

All commercial and military vessels cannot enter the designated zones without getting permission from the legitimate Yemeni government. The permitted ships will be subject to inspection prior to heading to Yemeni ports. ${ }^{4}$

Yemen authorized the coalition to implement enforcement measures to this end within the Yemeni territorial waters. On an operational level, coalition naval forces established a process of compulsory stopping and inspecting of vessels that were calling on the Yemeni ports, and which now had to obtain entry permission. ${ }^{5}$ This measure caused considerable queuing of shipping, massive time delays and uncertainty on what products would be allowed to enter. ${ }^{6}$ To solve these issues, apparently involved British advisers to the Saudi-led coalition urged for more intelligence-driven operations so as not to cause this hold-up of vessels waiting for inspection and possible entry outside the territorial waters of Yemen. ${ }^{7}$ At a press conference, the spokesman of the coalition forces, Major General Ahmad Assiri, stated that 'all ships assigned to implement the naval blockade on Yemeni ports and

\footnotetext{
${ }^{2}$ UN Security Council, Statement issued by the Kingdom of Saudi Arabia, the United Arab Emirates, the Kingdom of Bahrain, the State of Qatar and the State of Kuwait, UN Doc. S/2015/217 (27 March 2015), p. 4.

3 'US Backed Saudi Naval Blockade Leaves 20m Inside Yemen Facing Humanitarian Disaster', The Guardian, 6 June 2015, available at: http://www.mintpressnews.com/us-backed-saudi-naval-blockadeleaves-20m-inside-yemen-facing-humanitarian-disaster/206286/ (accessed 24 June 2017).

4 The statement is printed (in Arabic) in the Yemen Times, 12 April 2015, available at: http://www. yementimes.com/en/1875/news/5049/Naval-embargo-takes-effect.htm (accessed 25 June 2017).

5 See http://www.safety4sea.com/yemen-situation:-update-25128.

6 See for example to following blurb from Human Rights Watch (2015): 'The vessel's call log shows that the crew has tried to contact coalition forces over 250 times since the inspection. The log shows 37 responses by coalition forces, telling the vessel's crew that there was no information on whether permission had been granted. On April 28, at 5:30 p.m., the vessel was ordered to advance toward a position 14 nautical miles from Hodaida's port. At 9:30 p.m. it was ordered to leave Yemeni territorial waters again. Coalition forces contend that the vessel had received permission to berth at the port of Aden, but not Hodaida. The log shows the vessel's agent stating that the cargo is intended for delivery to Hodaida'.

7 'Saudi-led naval blockade leaves 20m Yemenis facing humanitarian disaster', The Guardian, 5 June 2015, available at: https://www.theguardian.com/world/2015/jun/05/saudi-led-naval-blockade-worsensyemen-humanitarian-disaster. The newspaper article states that: 'On western urging, Riyadh had promised to move towards "intelligence-led interdiction", stopping and searching individual ships on which there was good reason to believe arms were being smuggled, and away from a blanket policy of blocking the majority of vessels approaching Yemeni ports'.
} 
monitor the smuggling of weapons were in position in Yemeni waters' ${ }^{8}$ He also confirmed that the naval blockade had come into force. Other sources noted that next to weapons, other commodities, such as fuel, were also being stopped from entering Yemen. ${ }^{9}$ Shipping agencies advised the maritime community that sailing and transit outside the Yemen territorial waters in the Gulf of Aden and the Red Sea was still possible. ${ }^{10}$ As the Houthi grip on Yemen spread throughout the western part of Yemen, including the port city of Hodaida, the blockade focused on the closure of this port and the western coastal area.

Apart from the practical inspection challenges at sea, another issue concerning the implemented measures has been the negative effect that the blockade is felt to have on the civilian population in Yemen. The naval measures taken by the coalition are seen as severely detrimental to the humanitarian situation on land. The view was born that as an immediate result of the establishment of the measures a growing humanitarian disaster developed. It has been widely reported that the naval enforcement measures had a massive impact on the civilian population and Yemen was on the brink of a famine. Since its establishment there has been a continued call to lift the blockade in order to relieve the civilian population.

A few days after the naval enforcement measures were put in place, on 14 April 2015, the UNSC adopted UN resolution 2216 (2015) establishing an arms embargo to stop the supply of weapons to the Houthi rebels. Paragraph 15 of the resolution reads:

15. Calls upon Member States, in particular States neighbouring Yemen, to inspect, in accordance with their national authorities and legislation and consistent with international law, in particular the law of the sea and relevant international civil aviation agreements, all cargo to Yemen, in their territory, including seaports and airports, if the State concerned has information that provides reasonable grounds to believe the cargo contains items the supply, sale, or transfer of which is prohibited by paragraph 14 of this resolution for the purpose of ensuring strict implementation of those provisions; $\ldots$

This resolution did not, however, result in lifting the measures taken by the coalition. In fact, it bolstered the Yemeni and Saudi positions to keep enforcing an arms embargo within the territorial waters of Yemen. When by the end of April 2015 the coalition announced that the primary objectives of operation Decisive Storm had been achieved and henceforth Operation Renewal of Hope could commence, ${ }^{11}$ the new objectives of the new operation 'also include[d] building an

\footnotetext{
8 Al-Salmi (2015).

9 Human Rights Watch (2015). But see also the arrival of MV Amsterdam, chartered by the World Food Program, which, in May 2015, was able to arrive in port. See World Food Program (2015).

${ }^{10}$ See 'Yemen Bans Entry into Its Territorial Waters', World Maritime News, 13 April 2015, available at: $\quad$ http://worldmaritimenews.com/archives/157580/yemen-bans-entry-into-its-territorial-waters/ (accessed 25 June 2017).

11 'Saudi Ambassador: Operation Decisive Storm Achieved its Objectives', Press briefing Operation Renewal of Hope, 22 April 2015, available at: http://www.operationrenewalofhope.com/saudiambassador-operation-decisive-storm-achieved-its-objectives/\#sthash.yXgWQ4mr.dpuf (accessed 25 June 2017).
} 
international coalition to provide maritime security to protect commerce and to prevent the shipments of weapons by sea or air in line with UN resolution 2216, including enhanced monitoring and inspections'. ${ }^{12}$

In the meantime, albeit in a trickling and much delayed manner, ships were actually able to pass and enter into Yemeni ports. Human Rights Watch, for example, stated that:

According to shipping logs, since April 16 coalition forces granted permission to 19 ships carrying rice, grain, palm oil, steel, and timber permission to berth at Hodaida and Saleef ports, and they were able to unload their cargo. The data shows that permission was denied to three container vessels on April 20. In contrast, no fuel tankers have been able to berth at Yemeni ports since March 28 , though at least seven have tried, according to shipping records. ${ }^{13}$

In July 2015, the dire humanitarian situation prompted the European Parliament to condemn the coalition naval enforcement measures in a statement:

3. Condemns the destabilising and violent unilateral actions taken by the Houthis and military units loyal to ex-President Saleh; also condemns the air strikes by the Saudi-led coalition and the naval blockade it has imposed on Yemen, which have led to thousands of deaths, have further destabilised Yemen, have created conditions more conducive to the expansion of terrorist and extremist organisations such as ISIS/Da'esh and AQAP, and have exacerbated an already critical humanitarian situation;... ${ }^{14}$

Notwithstanding the public outcries and official statements, the naval enforcement measures have remained in place. In its latest resolution on Yemen in 2017, UN resolution 2342 (2017), the UNSC did, however, not explicitly condemn the coalition naval measures, but worded its concerns with the following paragraph:

Gravely distressed by the continued deterioration of the devastating humanitarian situation in Yemen, expressing serious concern at all instances of hindrances to the effective delivery of humanitarian assistance, including limitations on the delivery of vital goods to the civilian population of Yemen.

The UNSC appears, therefore, not so much to take an explicitly disapproving stand on the naval enforcement measures themselves, but is primarily concerned with the effective delivery of humanitarian aid in relation to these measures. As mentioned previously, all expressed concerns from different organizations have, however, not led to the lifting of the coalition's naval enforcement measures. In April 2017, the UN Special Rapporteur on human rights and international sanctions stated that the blockade is causing a famine and that 'the blockade involves grave breaches of the most basic norms of human rights law, as well as the law of armed conflict'. ${ }^{15}$

\footnotetext{
12 Ibid.

13 Human Rights Watch (2015).

14 European Parliament, Resolution 9 July 2015 on the situation in Yemen (2015/2760(RSP)).

15 Office of the United Nations High Commissioner for Human Rights (2017).
} 


\section{Analysis}

The very first problem in discussing the legality of the coalition naval enforcement measures off the coast of Yemen is that the necessary operational details of the coalition operations are, in fact, scarce in the public domain. As the footnotes of the history provided above show, the reconstruction is derived mainly from public sources, which may not be correct or complete. To further the discussion, however, I will proceed based on this history, keeping in mind that the facts may be (partly) incorrect. As mentioned in the introduction, the analysis is subdivided into four questions. Namely, does the law of blockade apply in this conflict? Has the coalition established a blockade in the legal sense of the word, a blockade stricto sensu? Are there other possible legal bases that can be applicable to these enforcement measures? And lastly, how do humanitarian considerations impact on the legality of the naval enforcement measures?

\subsection{The Applicability of the Laws of Naval Warfare}

The first question relates to the legal status of the conflict and the subsequent issue of the applicability of the legal regime of laws of naval warfare. The status of the ongoing conflict in Yemen is generally characterized as a NIAC between the Yemeni Government on the one hand and the Houthis on the other. ${ }^{16}$ Sustained hostilities taking place between the Yemeni Armed Forces and a non-governmental armed group and the use of force between both has reached a high enough intensity to be classed as more than merely internal disturbances. ${ }^{17}$ Furthermore, the Houthis appear to be organized in such a way that they are able to plan and sustain military operations and control territory. ${ }^{18}$ With regard to the Saudi-led coalition acting in support of the Yemeni Government, one could debate whether the conflict is a separate NIAC between the coalition and the Houthis, or whether the coalition is in fact part of the NIAC between the Yemeni Government and the Houthis. Either way, it will result in a NIAC.

The legal status of a NIAC complicates the applicability of the law of blockade, as it is generally recognized that the laws of naval warfare do not apply during NIACs. ${ }^{19}$ Although one could argue about the exact scope of the law of naval warfare and whether parts of it might actually apply during NIACs, such as the more protective 'Geneva' rules on sea warfare with regard to, for instance, the shipwrecked and hospital ships, it is clear that the law of blockade does not. As Heintschel von Heinegg notes: 'It is a correct statement of the contemporary law that, absent recognition of belligerency, the parties to a non-international armed conflict are not entitled to establish and enforce a naval blockade against foreign

\footnotetext{
16 See, e.g., Bellal (2015), p. 304.

17 See also Haddad (2014), pp. 20-33.

18 See for instance a map of Houthi controlled areas (14 October 2016), available at: http://www.bbc. com/news/world-middle-east-29319423.

19 See, e.g., Heintschel von Heinegg (2010), p. 325.
} 
flagged vessels'. ${ }^{20}$ As he points out, historical application of the law of blockade during a NIAC, for instance during the American Civil War, must be viewed within the context of a recognition of belligerency. To the author's knowledge no such statement of recognition has been made by any State in the Yemeni conflict. If the threshold of NIAC is passed in this conflict, the conclusion that must be drawn from it is that, although the laws of armed conflict applicable in a NIAC apply, the laws of naval warfare do not apply in the Yemeni conflict.

The importance of this conclusion is that, first, the parties to the conflict cannot base their enforcement authority on this subregime of the laws of armed conflict. In other words, they have no legal authority derived from the laws of naval warfare to establish and enforce a belligerent blockade. Second, and consequently, the blockading party can also not be held liable for breaching the laws of blockade, as this legal regime does not apply to the situation. The exclusion of the applicability of a certain part of international law means that, in principle, it cannot be breached. This, for instance, also implies that it does not make sense to discuss the San Remo Manual sections on humanitarian obligations in the context of the Yemeni blockade. It is, however, possible that the authority from the law of blockade has de facto been used, which would mean that it is used unlawfully. Which brings me to the second question.

\subsection{Are the Established Naval Enforcement Measures a Blockade Stricto Sensu?}

The second question is whether the coalition has established a blockade stricto sensu and is enforcing it as such, or whether the measures are a de facto blockade causing similar effects. ${ }^{21}$ The importance of this question is that if a blockade stricto sensu has been established, it has been done unlawfully and, therefore, has also been unlawfully enforced. If it is not a blockade stricto sensu, firstly, there cannot be an argument of unlawfully establishing and enforcing a blockade and secondly, the (third) question arises whether there are other legal bases that may provide a possible legal ground for the measures that have been taken.

The traditional law of blockade is a historically grown balance between belligerent and neutral interests based on the situation of an international armed conflict. This body of law, apart from the one rule in the Declaration of Paris $(1856),{ }^{22}$ is entirely based on international customary law. The most complete attempt to codify the law of blockade has been the Declaration of London (1909). The London Declaration has, however, never been ratified, and was during the First World War even abrogated by the English and French allies. ${ }^{23}$ Today, many authors $^{24}$ take the position that the provisions of the London Declaration and also

\footnotetext{
${ }^{20}$ Heintschel Von Heinegg (2012), p. 228.

21 Gatten (2015).

22 The rule states that a blockade has to be effective in order for it to be lawfully established.

23 Siney (1957), pp. 183-185.

24 One author argues that the blockade law has fallen into desuetude, mostly by virtue of inconsistent practice, and that therefore the London Declaration also cannot be relied upon Kennedy (2012).
} 
the San Remo Manual on International Law Applicable to Armed Conflicts at Sea (1995) can serve as the substantial basis for the law of blockade. Some even consider the San Remo Manual provisions to be a codification of customary law. This is also a view recently taken by the many committees of inquiry that investigated the Israeli blockade operations. ${ }^{25}$

The commentary in the San Remo Manual mentions that a 'blockade is the blocking of the approach to the enemy coast, or a part of it, for the purpose of preventing ingress and egress of vessels or aircraft of all States' ${ }^{26}$ The sections in the San Remo Manual also embody the well-known and generally accepted conditions of notification, impartiality and effectiveness that form the basis for a blockade to be legally established and which opens the door to far-reaching authority for the blockading force. The practical result of these conditions is that, to put it simply, during a blockade nothing is meant to pass in or out of the blockaded port or coast. This is inherent to the conditions of the establishment of a blockade. As Heintschel von Heinegg mentions in the context of the Israeli Gaza blockade, "when one wants to maintain a blockade one has no choice but to prevent all vessels from entering or leaving the blockaded area'. ${ }^{27}$ Two exceptions can be mentioned. The first is the authority of a blockading State to authorize the passing of humanitarian aid shipping, an action that does not affect the conditions of effectiveness or impartiality of the blockade. Second is the passing of neutral warships, which does not affect the legality of the blockade. ${ }^{28}$

To answer the second question, the actual facts at sea are important and at the same time hard to establish. In terms of chronology, it appears that the coalition force publicly announced that they were stopping arms flowing into Yemen from the sea before the Yemeni Government formally announced it would close off the Yemeni territorial waters. There is no information available on whether the coalition actually stopped and searched vessels in the intervening time. Sands, Clapham and Ní Ghrálaigh mention that:

The intensity of the blockade has reportedly varied over time. Whereas it originally consisted of a full blockade of Yemeni ports, prohibiting all but a limited number of aid shipments, restrictions have since been somewhat

\footnotetext{
${ }^{25}$ Human Rights Committee, Report of the international fact-finding mission to investigate violations of international law, including international humanitarian and human rights law, resulting from the Israeli attacks on the flotilla of ships carrying humanitarian assistance, UN Doc. A/HRC/15/21 (27 September 2010) (Lebanon), para. 50; Report of the Secretary-General's Panel of Inquiry on the 31 May 2010 Flotilla Incident (Palmer report), September 2011, para. 157, available at: https://www.un.org/News/dh/ infocus/middle_east/Gaza_Flotilla_Panel_Report.pdf; Report of the Public Commission to Examine the Maritime Incident of 31 May 2010 (Turkel Commission), January 2011, available at: http://www. globalsecurity.org/military/library/report/2011/turkel_israel_flotilla_p1_1101.pdf (accessed 11 July 2017).

26 San Remo Manual, Doswald-Beck (1995), p. 176.

27 Heintschel von Heinegg (2012), p. 229.

28 On the latter point debate exists on whether this is an enforceable right for neutral warships, or whether it is an accepted exception to the obligation of impartiality and effectiveness for a blockading State. Interestingly, the issue is not wholly theoretical in the context of Yemen, as Iranian warships, and it is said that Iran is backing the Houthis, were said to be in the region.
} 
reduced: vessels must now reportedly be approved and inspected by Coalition forces in order to enter Yemen's territorial waters. ${ }^{29}$

They may possibly be right, but be that as it may, it is clear that the situation developed into an inspection procedure in which vessels are potentially able to pass after being duly inspected, rather than a procedure of stopping all ingress and egress for the purpose of closing off the ports. ${ }^{30}$ Apparently, the coalition naval forces did not aim to impose an actual naval blockade operation, in which the purpose is to stop the ingress and egress of all vessels. Instead, the measures are more likely aimed at conducting inspection procedures within the territorial waters of Yemen in order to stop material that might be useful against the coalition when in the hands of the enemy, such as weapons, but also other possible 'contraband' items, such as oil, gas and fuel. The concept of operations may indeed have resulted in a de facto blockade, with vessels having to queue, wait and possibly be refused entry into port. One notice from the UK Hydrographic Office, in a procedure to follow for vessels calling at Yemeni ports, stated that vessels must obtain permission to enter. It does however not state that no vessel can enter or leave. ${ }^{31}$

In May 2016, the Yemeni Government announced that entry permission into Yemeni ports (Hodaida, Saleef and Makha) is to be obtained through the United Nations Verification and Inspection Mission for Yemen (UNVIM) ${ }^{32}$ that has been installed in support of resolution $2216 .{ }^{33}$ The UN Secretary-General stated that UNVIM is to:

facilitate the unimpeded flow of commercial goods and services to Yemen, while ensuring compliance with the arms embargo established pursuant to Security Council resolution 2216 (2015). It should provide fast and impartial clearance services for shipping companies transporting commercial imports and bilateral assistance to Yemeni ports outside of the authority of the Government of Yemen. ${ }^{34}$

The procedure put into place by UNVIM certainly does not look as if it aims to deny all traffic entry or exit from the Yemeni ports.

Another indicator that may point in the direction that the coalition itself did not consider itself to be using the law of blockade, is that the measures are not taken outside the Yemeni territorial waters. The operational stand-off distance of a blockading force is not hampered by the international law of the sea because of the

\footnotetext{
${ }^{29}$ Sand et al. (2015).

30 Also the UN Panel of experts on Yemen established pursuant to Security Council resolution 2140 (2014) provided (in annex 9) a list of vessels that went through the inspection process of the coalition. Based on this list it is, however, hard to tell whether these vessels have actually been allowed to pass. See UN Security Council, Final report of the Panel of Experts on Yemen established pursuant to Security Council resolution 2140 (2014), UN Doc. S/2016/73 (26 January 2016), pp. 69-70.

31 UK Hydrographic Office (2016).

32 Republic of Yemen, Ministry of Transport, 2 May 2016, available at: https://vimye.org/docs/GoY\% 20Announcement\%20of\%20UNVIM\%20Launch.pdf (accessed 23 June 2017). See also the UNVIM homepage at: https://vimye.org.

33 Republic of Yemen, Ministry of Transport, 2 May 2016, above n. 32.

34 UNSG (2016).
} 
view that during international armed conflict the high seas are allowed to be used for military operations. ${ }^{35}$ This authority is not so much connected to establishing blockades as a particular authority in blockade warfare, ${ }^{36}$ but to the idea that in interstate warfare the global commons of the sea can be used for hostilities. The only consideration of the international law of the sea that could have some effect on the establishment is the due-regard rule that applies in international waters. Although operationally the distance taken by the blockading force is determined by military requirements, which could have taken it further out to international waters, ${ }^{37}$ the enforcement measures with regard to Yemen remained within the limits of the territorial sea. Now that it has been established above that the laws of naval warfare do not apply, there is also no legal ground to apply the measures outside the territorial waters.

Interestingly, the public press statements from the coalition were getting wise to the terminology with regard to the naval enforcement measures. Where at the beginning of the operation the spokesmen spoke of a blockade, this was changed into a denial of having established a blockade stricto sensu. In 2016 the military spokesperson stated:

The Saudi-led coalition denied on Tuesday it had imposed a 'blockade' on Yemen, saying instead that it was only controlling access to the country to prevent pro-Iran rebels from obtaining arms. 'No, there is no blockade', coalition spokesman Major General Ahmed Assiri told AFP. 'There is control based on international law... Control is different from blockade, which means that nobody can enter or leave the country', he said. Assiri also spoke of 'restriction' and 'controlled freedom of movement'.

Based on what is publicly available, there are sufficient grounds to conclude that no blockade stricto sensu has been established, but measures that may have a similar effect. If this is indeed the case, it is hard to argue that a breach of international law has taken place by unlawfully using the legal authority of the law of blockade. ${ }^{39}$

\subsection{Other Legal Bases to Establish Naval Enforcement Measures}

Let us assume that the laws of naval warfare do not apply and no blockade stricto sensu has been established. Still, naval enforcement measures are in place. Is there any other legal basis that may serve to support these measures? Two legal bases can

\footnotetext{
35 See San Remo Manual, Doswald-Beck (1995), Sect. 10.

36 It could implicitly follow from the rule that blockades may not bar access to neutral ports (also stated in Art. 18 London Declaration), but merely in the most remote sense: the wider the blockaded area, the more chance there is that access to neutral ports will be blocked.

37 The military requirements could for example consider staying far away enough from coastal threats balanced with effectively closing off a port. The several land-to-sea attacks that have occurred against shipping in the Bab-ell Mandeb Strait are examples of coastal threats that may impact on the stand-off distance of a blockade.

38 See http://www.arabnews.com/node/1002346/middle-east.

39 See, e.g., the discussion on the Opinio Juris blog entry of E. Kontorovic on the Yemen blockade Kontorovic (2015).
} 
be looked at in particular. First is the combination of State consent and the international law of the sea. Second is the Security Council's resolution 2216.

The earlier mentioned statement of 10 April 2015 stated that the enforcement measures were to be undertaken within the territorial sea of Yemen. The Yemeni Government itself mentioned that it is using force in self-defence, in the context of Article 51 of the UN Charter. The request to join Yemen against the Houthis was made in the same context. Were one to follow this path, arguably, the coalition would be acting on the basis of collective self-defence against the Houthi opponents, as the coalition is acting on the request and with the consent of the Yemeni Government. The Yemeni Government has sovereign powers over its territorial and internal waters. Within the $12 \mathrm{~nm}$ space of the territorial waters Yemen has, therefore, sovereign powers with respect to controlling the shipping and the entering or leaving of ports. Within the limitations of Article 25(3) of the Law of the Sea Convention (UNCLOS) a State can also suspend the right of innocent passage. This Article reads:

3. The coastal State may, without discrimination in form or in fact among foreign ships, suspend temporarily in specified areas of its territorial sea the innocent passage of foreign ships if such suspension is essential for the protection of its security, including weapons exercises. Such suspension shall take effect only after having been duly published.

Whatever is taking place exactly with regard to inspection and refusals of entries into ports within the territorial waters of Yemen, it is within the power of a sovereign State and does not breach any authority given to other users of the sea based on the international law of the sea. A very strict ingress policy or even the closure of ports and the suspension of innocent passage essential for the protection of State security may be possible. Although shipping agencies have at the beginning of the conflict been advising keeping clear of the Yemeni territorial waters, it appears that the latter measure of suspending innocent passage has not been formally taken. ${ }^{40}$ This, however, does not stop Yemen's right to implement a very strict ingress procedure into the Yemeni ports.

The second legal basis that can be considered is UN resolution 2216 (2015). The core issue that emerges here is the geographical scope of the imposed arms embargo and what authority the resolution mandates in the different maritime zones, in particular in the territorial sea and the high seas. With regard to the territorial sea, from the resolution's key paragraphs (14-17) it is clear that the resolution calls upon States to enforce the arms embargo within the territory of States. Yemen's territory is no exception to this. Yemen can, therefore, enforce the resolution within its territory, which includes the internal waters and territorial sea. A possible legal basis in these maritime zones therefore exists for enforcing the arms embargo. Actual enforcement of the arms embargo should be governed by national legislation on UN sanctions implementation.

\footnotetext{
40 According to the website of the Division for Ocean Affairs and the Law of the Sea (DOALOS) there is no official record that Yemen has suspended innocent passage. See http://www.un.org/depts/los/ convention_agreements/innocent_passages_suspension.htm (accessed 23 June 2017).
} 
With regard to the high seas, the point to underline is that the resolution does not explicitly authorise the enforcement of a maritime embargo operation at sea. Even if one were to push the text of the resolution to implicitly read as a basis for enforcing the resolution on the high seas, it would be under the limitation that the enforcement would need to be in line with the international law of the sea, as the resolution expressly states. In contrast to the law of naval warfare, the international law of the sea does not provide for any enforcement measures on the high seas that are even remotely akin to blockade measures. Rather, the exclusive jurisdiction of the flag State is leading in that regard. The resolution can, therefore, not be a legal basis for enforcing an arms embargo on the high seas.

Interestingly, patrolling of the high seas around Yemen apparently does happen. According to the UN Panel of Experts on Yemen:

63. Coastal dhows, if en route to Houthi-Saleh-controlled ports on the west coast of Yemen, even if routed via a transit point in Djibouti or Somalia, must pass from the Gulf of Aden into the Red Sea through the busy Bab al-Mandab strait, which is $28 \mathrm{~km}$ wide. This is well patrolled by the Combined Maritime Forces, the United States Navy Fifth Fleet and the Royal Saudi Navy. If sent in very small consignments on coastal dhows, it is probable that some shipments would arrive, but many would inevitably be interdicted by naval patrols. The Panel has seen no evidence of any maritime seizures to date on this route, which strongly suggests that it is not being actively exploited. ${ }^{41}$

According to the same report, during 2015 and 2016 four interdicted ships had cargo that was confirmed seized by Australian and American warships:

66. There were only four confirmed seizures of weapons in the Arabian Sea and the Gulf of Aden by the Combined Maritime Forces or the United States Navy Fifth Fleet during 2015 and 2016, together with an alleged seizure by the coalition led by Saudi Arabia in 2016 (see table 2).

These vessels and weapons were, however, seized under the arms embargo mandates of UN resolutions 2182 (2014) and 2244 (2015) that were set up with regard to the Somalia situation. ${ }^{42}$ Although the proximity to other, overlapping, conflict areas is creating other possible legal bases for seizing arms in the maritime area on the high seas around the Horn of Africa, it does not create a ground for seizing weapons on the high seas with regard to Yemen. Following this wider look at different conflicts taking place in the Yemeni region, even if one were to argue that yet another conflict must be taken into consideration, namely the conflict between Yemen and the United States and terrorist organizations such as Al Qaida and/or IS, still no conclusion can be drawn that an international armed conflict exists to which the laws of naval warfare would apply. To conclude, the resolution with regard to Yemen imposes an arms embargo that States can enforce within their own

\footnotetext{
${ }^{41}$ UN Security Council, Final report of the Panel of Experts on Yemen, UN Doc. S/2017/81 (31 January 2017), p. 26.

42 Ibid., p. 27, table 2.
} 
territory. There is, however, no authority that can be derived from the resolution to enforce an arms embargo outside the territorial waters of a State.

There is no clear statement by the Yemeni Government on what the exact legal basis of the naval measures is. The coalition spokesperson, Major General Ahmad Assiri, stated in this regard that:

'If a boat leaves from Djibouti, before reaching Hodeida (port in western Yemen), our forces board the vessel to ensure the cargo is legal and complies with Resolution 2216, adopted by the UN Security Council in April 2015 and prohibiting the delivery of arms to the rebels in Yemen', he said. ${ }^{43}$

It can be argued that the combination of consent and conducting coalition operations only in the territorial sea of Yemen does not breach international law and can arguably be said to be in support of the UN resolution. Were these naval measures to be taken outside the territorial sea, then the resolution would not support such operations, nor would this be possible under the general international law of the sea. The set-up of the UNVIM procedures, based upon the UN resolution, for entering Yemeni ports and the statement of the coalition spokesperson gives a good indication for the resolution being part of the legal basis for the inspections, or at least legitimizes the coalition's activities. One other reference that supports that is the view of Akande and Gillard, which mentions that 'The Saudi-led coalition was overseeing the implementation of the arms embargo imposed by the Security Council...'. 44

\subsection{Humanitarian Considerations and Blockade}

The fourth and last question to remark on relates to the issue of humanitarian considerations in relation to blockades. As mentioned earlier, there is a widely-held view that the naval measures have an immensely negative impact on the civilian population. Support for the unlawfulness of the naval measures is looked for and found within the law of blockade and the San Remo Manual, the latter of which contains a section on the lawfulness of blockades in relation to starvation. If, however, the approach set out above is followed whereby the view is put forward that the law of blockade does not apply, it does not make real sense to discuss the relationship between humanitarian considerations and the law of blockade. The consequence of the conclusions to the first three questions dismissed the application of the law of blockade and its possible humanitarian requirements. It would probably be better to argue that a State has breached its obligations under the rules of the prohibition on starvation or access to humanitarian aid than to confuse this with the law of blockade, which does not apply. The naval measures may not be a violation of the laws of naval warfare, but it may arguably be unlawful under the broader rules of the laws of armed conflict, such as Articles 14 and 18 of Additional Protocol II to the 1949 Geneva Conventions (APII) concerning the population's

\footnotetext{
43 'Saudi Arabia denies it imposed Yemen blockade', Middle-East online, 25 October 2016, available at: http://www.middle-east-online.com/english/?id=79476.

44 Akande and Gillard (2017), p. 135.
} 
access to humanitarian relief. The debate would then centre on the question of whether the naval measures are conducted in such a manner that they cause starvation, whether consent for relief shipping is withheld unlawfully, and whether enough is done to allow humanitarian relief to pass through the inspections. ${ }^{45}$ Whether they actually do, falls outside the scope of this article. What is at least made clear here is that possible unlawfulness cannot be determined by looking at the law of blockade.

Although in this particular situation it is argued that the law of blockade does not apply, but if it did, a few points on the relationship between humanitarian considerations and the law of blockade can be raised. Currently the only humanitarian consideration the law of blockade contains is that a blockading force can, under the conditions of the blockading force, allow aid shipping to pass without hampering the condition of effectively and impartially establishing a blockade. An effective blockade will most certainly, and in fact needs to, have an impact; that is the operational purpose of a blockade. ${ }^{46}$ The impact of a blockade can depend on the purpose of the blockade, which can be military or economic, or both. ${ }^{47}$ Interestingly, in section 102 of the San Remo Manual the humanitarian consideration of starvation and the conditions for establishing a lawful blockade have been merged into one rule. It states:

102. The declaration or establishment of a blockade is prohibited if:

(a) it has the sole purpose of starving the civilian population or denying it other objects essential for its survival; or

(b) the damage to the civilian population is, or may be expected to be, excessive in relation to the concrete and direct military advantage anticipated from the blockade.

Not surprisingly, this section is often quoted in the context of the unlawfulness of the Yemeni enforcement measures. In an earlier article I suggested with regard to this section of the San Remo Manual that the law of blockade has seen an increasing willingness to embrace more humanitarian conditions or principles that put further restraints on the manner in which a blockade is established and enforced. ${ }^{48}$ The Yemeni situation is another case in point where the humanitarian considerations and blockade have been merged together in a legal discussion. But viewed realistically, no State will probably ever state that their blockade has the intentional aim of starving a population. Discussion will rather centre on the second paragraph of section 102, in the context of whether enough food and other essential products are entering into Yemen so that the blockade can be deemed proportional. What this

\footnotetext{
45 See elaborately on the unlawfulness of impeding humanitarian relief operations Akande and Gillard (2017).

46 See also Heintschel von Heinegg, who states: 'A blockade will always have negative impacts on the supply of the civilian population with food, drinking water, medical items, and other objects essential for its survival'. Heintschel von Heinegg (2015), para. 8 .

47 In a military sense blockades are divided into fleet blockades and economic blockades. The first focuses on a denial of the use of the sea by enemy forces. The second focuses on the economic lines of communication of the enemy.

48 Fink (2011).
} 
also implies, is that if the damage to the civilian population is not excessive as regards the blockade in relation to the direct military advantage anticipated from the blockade, it is not prohibited. In other words, the effect (rather than the purpose) of starvation does not by definition render a blockade unlawful. ${ }^{49}$

Finally, sections 103 and 104 of the San Remo Manual are also interesting to note, because they deal with humanitarian aid shipping.

103. If the civilian population of the blockaded territory is inadequately provided with food and other objects essential for its survival, the blockading party must provide for free passage of such foodstuffs and other essential supplies, subject to:

(a) the right to prescribe the technical arrangements, including search, under which such passage is permitted; and

(b) the condition that the distribution of such supplies shall be made under the local supervision of a Protecting Power or a humanitarian organization which offers guarantees of impartiality, such as the International Committee of the Red Cross.

104. The blockading belligerent shall allow the passage of medical supplies for the civilian population or for the wounded and sick members of armed forces, subject to the right to prescribe technical arrangements, including search, under which such passage is permitted.

The above-mentioned sections of the San Remo Manual attempt to translate the API and APII obligations on access to humanitarian relief to a maritime environment. They are progressive in the sense that they underline that, for instance, the blockading Party must provide free passage to humanitarian aid, whereas the traditional law of blockade only went as far as to accept that letting humanitarian aid pass should not hamper the effectiveness of the blockade. They are also progressive in the sense that proportionality is introduced into the question of unlawfulness. The merging of the rule regarding starvation and the law of blockade is tempered as it appears to need an intent, whereas on land the dimension of unlawfulness is based on the fact that military actions cause starvation.

\section{Concluding Remarks and Reflections}

A hard case regarding the legal issues surrounding the 'Yemen blockade' cannot be made without a good understanding of the operational facts at sea. And those are hard to obtain. Based on the information that is publicly available, there is, however, a good argument to be made that the laws of naval warfare-and the law of blockade in particular-are not applicable to the naval enforcement measures that are imposed in Yemen's territorial sea. Neither has an actual blockade stricto sensu been established. Instead, alternative legal bases exist for the naval enforcement measures off the coast of Yemen undertaken by the coalition's naval forces. Two of these are the sovereign

\footnotetext{
49 See also the Commentary on Rule 54 IHL customary law study. Henckaerts and Doswald-Beck (2005), p. 189.
} 
powers of the State over its own territorial sea and a UN resolution. Although the latter, in this case, does not explicitly authorize enforcement on the high seas, the coalition appears to stay within the UN arms embargo mandate as the operation is conducted with regard to the territorial sea of Yemen. If one were to follow the argument that the laws of naval warfare do not apply in the Yemeni situation, the San Remo Manual sections with regard to blockade and humanitarian aid cease to be relevant. A possible case to be made with regard to the dire humanitarian situation is more likely to succeed by way of the international humanitarian law applicable to NIACs, rather than via the laws of naval warfare.

As a reflection with which to conclude it can be said that the 'Yemen blockade' is an interesting case in point for the broader discussion on the applicability of the laws of naval warfare in a NIAC. Since the Mavi Marmara incident during Israel's Operation Sea Breeze in May 2010, the question of the applicability of the law of blockade, and the law of naval warfare in general, to NIACs and against non-state actors (NSA) has moved a little to the foreground. Against the background of adapting naval operations to counter contemporary threats, some legal experts are beginning to propose its applicability to NIACs, albeit with certain modifications. Professor McLaughlin, for instance, opined that: 'I think it uncontentious, for example, that a State may impose a blockade [...] against territory substantially controlled by a terrorist group which is also an OAG engaged in an armed conflict with that State...' ${ }^{50}$ Here and there one can find sympathy for applying the laws of naval warfare in situations other than international armed conflict. The challenging part with regard to the nature of the conflict argument is that current conflicts continue to raise debate on what the nature of the conflict actually is. The question of determination of the Gaza and Lebanon conflicts, or the attribution of Hezbollah violence to the state of Lebanon has filled bookshelves with a myriad of opinions. ${ }^{51}$ Be that as it may, and even though the Yemeni naval operations may arguably not be considered through the lens of the law of blockade, it remains a fact that naval forces are again used in NIACs and in a blockading type of role. If within modern conflicts States will have an operational need to use the method of blockade in a situation outside international armed conflict, it merits further thought on how that would be legally sustainable. My prediction at this stage is that it would be unthinkable that if the law of blockade were to further evolve into NIAC law, protective or humanitarian considerations will be left out of the new balance between rights and duties for belligerents, neutrals and individuals subject to blockade.

Open Access This article is distributed under the terms of the Creative Commons Attribution 4.0 International License (http://creativecommons.org/licenses/by/4.0/), which permits unrestricted use, distribution, and reproduction in any medium, provided you give appropriate credit to the original author(s) and the source, provide a link to the Creative Commons license, and indicate if changes were made.

\section{References}

Akande D, Gillard E (2017) Promoting compliance with the rules regulating humanitarian relief operations in armed conflict: some challenges. Isr Law Rev 50(2):119-137

50 McLaughlin (2011), p. 403.

${ }^{51}$ E.g. Darcy and Reynolds (2010); Schmitt (2008); Ducheine and Pouw (2009). 
Al-Salmi W (2015) Yemen authorises Arab naval blockade. The New Arab, 12 April 2015. http://www. alaraby.co.uk/english/news/2015/4/12/yemen-authorises-arab-naval-blockade. Accessed 23 June 2017

Bellal A (ed) (2015) The war report: armed conflict in 2014. Oxford University Press, Oxford

Darcy S, Reynolds J (2010) An enduring occupation: the status of the Gaza strip from the perspective of international humanitarian law. J Confl Secur Law 15(2):211-243

Doswald-Beck L (ed) (1995) San Remo Manual on international law applicable to armed conflicts at sea. Cambridge University Press, Cambridge

Ducheine PAL, Pouw E (2009) Operation change direction: a short survey of the legal basis and the applicable legal regimes. In: De Weger M, Osinga F, Kirkels H (eds) Complex operations: studies on Lebanon (2006) and Afghanistan (2006-present). NL-ARMS. Faculty of Military Sciences of the NLDA, Faculty Research Office, Breda, pp 51-69

Fink M (2011) Contemporary views on the lawfulness of naval blockades. Aegean Rev Law Sea Marit Law 1:191-215

Gatten E (2015) Saudi blockade starves Yemen of vital supplies, as bombing raids continue. Independent, 19 September 2015. http://www.independent.co.uk/news/world/middle-east/saudi-blockade-starvesyemen-of-vital-supplies-as-bombing-raids-continue-10509460.html. Accessed 23 June 2017

Haddad S (2014) Yemen. In: Arimatsu L, Choudhury M (eds) The legal classification of the armed conflicts in Syria, Yemen and Libya. Chatham House, London, pp 20-33

Heintschel von Heinegg W (2010) The law of military operations at sea. In: Gill TD, Fleck D (eds) The handbook of international law of military operations. Oxford University Press, Oxford, pp 325-374

Heintschel von Heinegg W (2012) Methods and means of naval warfare in non-international armed conflict. In: Watkin K, Norris AJ (eds) Non-international armed conflict in the twenty-first century, vol 88. International law studies. Naval War College, New Port, pp 211-236

Heintschel von Heinegg W (2015) Blockade. Last updated October 2015. In: Max Planck encyclopedia of public international law (MPEPIL). Oxford University Press. Oxford (online version)

Henckaerts JM, Doswald-Beck L (2005) Customary international humanitarian law, vol I. Cambridge University Press, Cambridge

Human Rights Watch (2015) Yemen: coalition blocking desperately needed fuel. 10 May 2015. https:// www.hrw.org/news/2015/05/10/yemen-coalition-blocking-desperately-needed-fuel. Accessed 10 July 2017

Kennedy I (2012) Practice makes custom: a closer look at the traditional law of naval blockade. Univ Tor Fac Law Rev 70:10-35

Kontorovic E (2015) Guest post: Iran's relief ship and the blockade of Yemen. Opinio Juris, 11 May 2015. http://opiniojuris.org/2015/05/11/guest-post-irans-relief-ship-and-the-blockade-of-yemen/. Accessed 25 June 2017

McLaughlin R (2011) 'Terrorism' as a central theme in the evolution of maritime operations law since 11 September 2001. Yearb Int Humanit Law 14:391-409

Office of the United Nations High Commissioner for Human Rights (2017) Lift blockade of Yemen to stop 'catastrophe' of millions facing starvation, says UN expert. 12 April 2017. http://www.ohchr. org/EN/NewsEvents/Pages/DisplayNews.aspx?NewsID=21496\&LangID=E. Accessed 20 June 2017

Sand P, Clapham A, Ní Ghrálaigh B (2015) The lawfulness of the authorisation by the United Kingdom of weapons and related items for export to Saudi Arabia in the context of Saudi Arabia's military intervention in Yemen. https://www.amnesty.org.uk/files/webfm/Documents/issues/legal_opinion_ on_saudi_arms_exports_16_december_2015_correction.pdf. Accessed 23 June 2017

Schmitt MN (2008) 'Change Direction' 2006: Israeli operations in Lebanon and the international law of self-defense. In: Carsten MD (ed) International law and military operation, vol 84. International law studies. Naval War College, New Port, pp 265-304

Siney M (1957) The allied blockade of Germany 1914-1916. University Michigan Press, Ann Arbor

UK Hydrographic Office (2016) Security related information to mariners Q6099/2016/001. https://www. admiralty.co.uk/AdmiraltyDownloadMedia/Security\%20Related\%20Information\%20to\%20Mariners/ Q6099-2016-001.pdf. Accessed 25 June 2017

UNSG (2016) Secretary-General welcomes new United Nations verification mechanism in Djibouti to facilitate flow of goods, services into Yemen. Press release SG/SM/17730, 3 May 2016. https:// www.un.org/press/en/2016/sgsm17730.doc.htm. Accessed 11 July 2017

World Food Program (2015) WFP-chartered ship docks in Yemen with fuel for humanitarian operations. http://www.wfp.org/news/news-release/wfp-chartered-ship-docks-yemen-fuel-humanitarian-operations. Accessed 24 June 2017 